\title{
Cabbage Palm Caterpillar, Litoprosopus futilis (G. \& R.) (Insecta: Lepidoptera: Noctuidae: Ophiderinae) $)^{1}$
}

G.W. Dekle ${ }^{2}$

\section{Introduction}

The cabbage palm caterpillar, sometimes referred to as the cabbage palm worm, is the larva of an owlet moth. The larva was described by S.E. Crumb from one inflated U.S. National Museum specimen collected on saw palmetto, Serenoa repens (Bartr.), Astoria, Florida, by H.G. Dyar. Crumb reported the larva probably feeds on the old dry leaf bases of cabbage palmetto (Sabal palmetto (Walt. Lodd.)). The author has collected larvae feeding on the inflorescence of cabbage palmetto. A.R. Grote and C.T. Robinson described the adult moth in 1868 as Dyops futilis Grote \& Robinson.

\section{Distribution}

The cabbage palm caterpillar is distributed throughout much of Florida. However, populations vary geographically and through time. DPI records indicate caterpillar infestations at the following locations: Atlantic Beach (Nov.), Casey Key (July), Cocoa (Aug.), Crestview (May), Daytona Beach (Nov.), DeLeon Springs (July), Flagler Beach (April), Ft. Pierce (Aug.), Frostproof (July), Gainesville (April), Geneva (Aug.), Groveland
(Nov.), Harbor Oaks (July), Homestead (June), Jacksonville Beach (June), Key West (March), Largo (Sept.), Lemon Bluff (July), New Smyrna Beach (Aug.), Oak Hill (Aug.), Palm Valley (July), Patrick AFB (Sept.), Ruskin (Oct.), St. Augustine (Aug.), Sanford (June), Sun City (March), Tampa (Aug.), Titusville (Aug.), Vero Beach (Sept.), Winter Garden (June), Winter Haven (May).

\section{Description}

\section{Larvae}

The mature larva is about $11 / 2$ inches in length. The skin is covered with very small black spines, which are not visible to the naked eye. The body appears pinkish in color; the head and cervical shield are shiny black. When examined under low magnification (10x), the larva is taffy colored with pinkish stripes extending from the cervical shield to the last abdominal segments. Extremely long, strong and white primary setae arise from shiny black conical body tubercles. Setigerous tubercles $1 \mathrm{a}$ and $1 \mathrm{~b}$ are fused on the mesothorax and metathorax. The black bases of setae 1a and 1b on the mesothorax are ringed with white; this is a very useful diagnostic

1. This document is EENY-095 (originally published as DPI Entomology Circular No. 75), one of a series of Featured Creatures from the Entomology and Nematology Department, Florida Cooperative Extension Service, Institute of Food and Agricultural Sciences, University of Florida. Published: July 1999. This document is also available on Featured Creatures Website at http://creatures.ifas.ufl.edu. Please visit the EDIS Website at http://edis.ifas.ufl.edu. 2. G.W. Dekle, Florida Department of Agriculture and Consumer Services, Division of Plant Industry, Gainesville, FL.

The Institute of Food and Agricultural Sciences (IFAS) is an Equal Employment Opportunity - Affirmative Action Employer authorized to provide research, educational information and other services only to individuals and institutions that function without regard to race, creed, color, religion, age, disability, sex, sexual orientation, marital status, national origin, political opinions or affiliations. For information on obtaining other extension publications, contact your county Cooperative Extension Service office. Florida Cooperative Extension Service / Institute of Food and Agricultural Sciences / University of Florida / Larry R. Arrington, Interim Dean 
character of the larva. The spiracles are entirely black. Prolegs with crochets in a mesoseries are present on abdominal segments $3,4,5$, and 6 . The larva becomes very pink just before pupating.

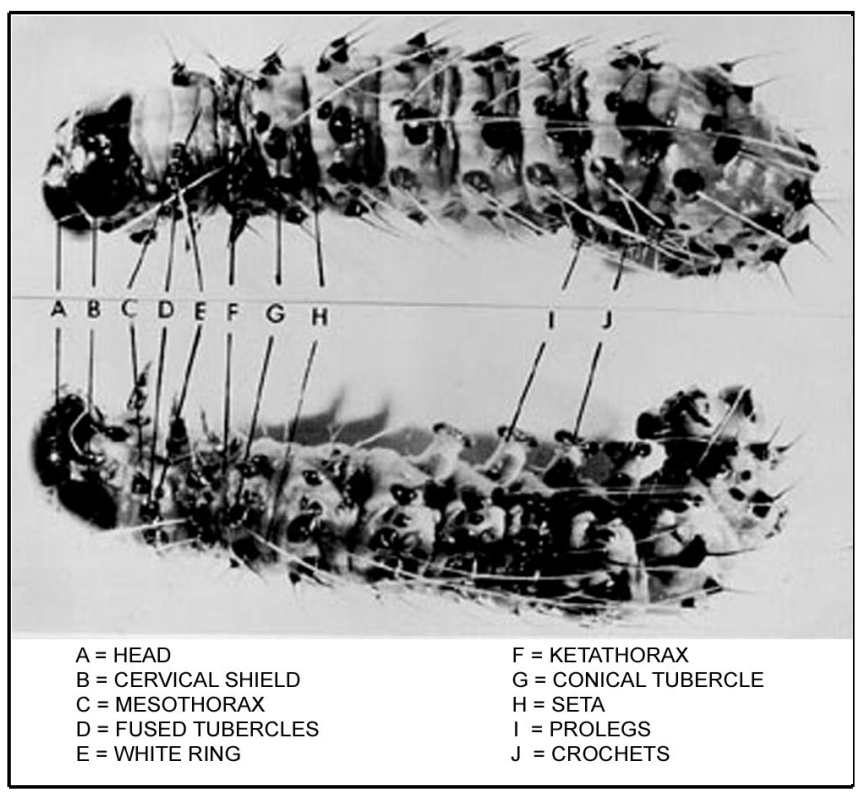

Figure 1. Cabbage palm caterpillar, Litoprosopus futilis (G. \& R.). with body parts identified. Credits: Division of Plant Industry

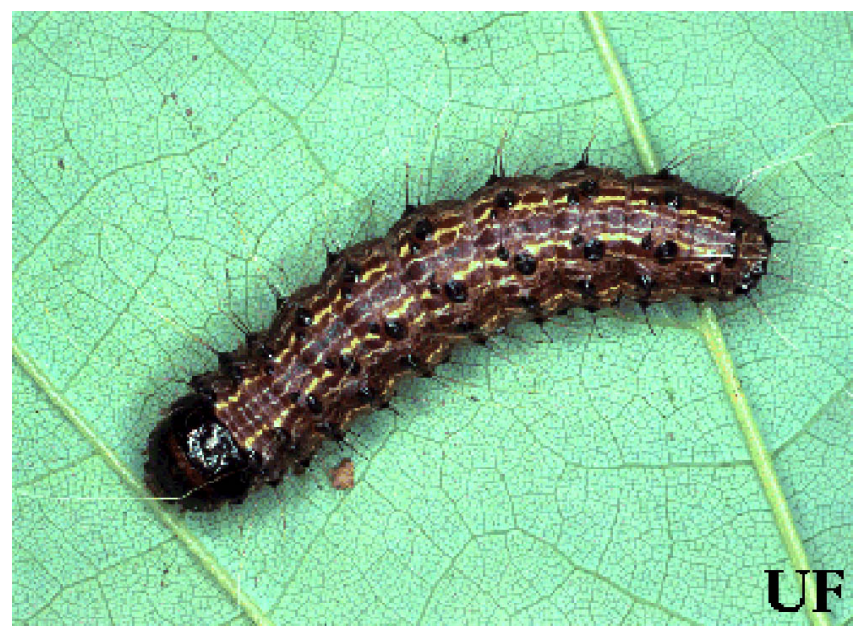

Figure 2. Cabbage palm caterpillar, Litoprosopus futilis (G. \& R.). Credits: University of Florida

\section{Pupa}

A tough cocoon protects the dark reddish brown pupa.

\section{Adult}

The adult moth is fawn colored and has a wing expanse of about 2 inches. The body is concolorous with the forewings. A dark eyespot about 3/16 inch in

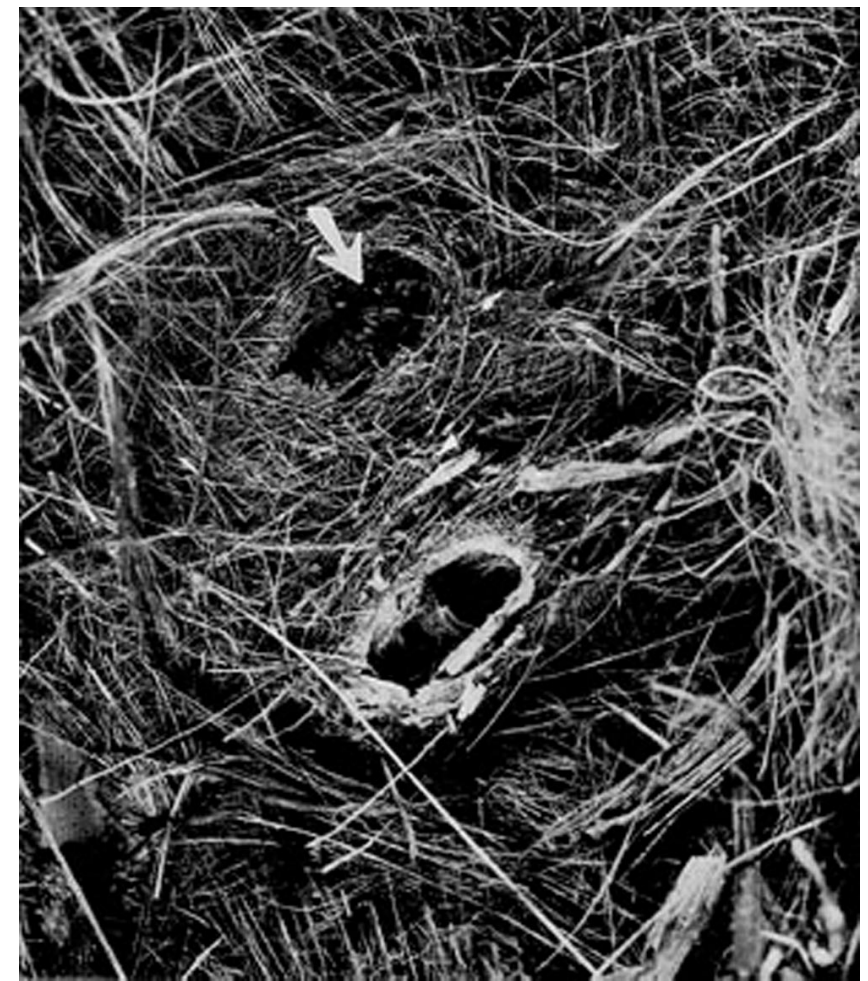

Figure 3. Cocoons of the cabbage palm caterpillar, Litoprosopus futilis (G. \& R.), constructed from palm fibers (arrow points to pupa). Credits: Division of Plant Industry

diameter is found on each hind wing. Within each spot are two, approximately parallel, white linear dashes.

\section{Hosts}

The Division of Plant Industry has recorded the cabbage palm caterpillar on numerous plants. It is the opinion of the author that all host records on plants other than palm are erroneous. Although DPI plant specialists have collected larvae on various plants, it is doubtful that these represent valid host records. All records for Litoprosopus futilis G. \& R. feeding on Sabal are valid. One record in the DPI file lists palm, Washingtonia, as a host; the author accepts this host.

\section{Field Observations}

The following account is from observations made by R.W. Massie, Geneva, Florida: the palm caterpillar can usually be found on the cabbage palm at the time the embryonic bloom is in the small green bud stage. Tiny larvae may be found deep in the developing bloom spikes. The larvae sometimes gather in the thousands on the immature buds, entirely denuding the trees of all trace of bloom as 


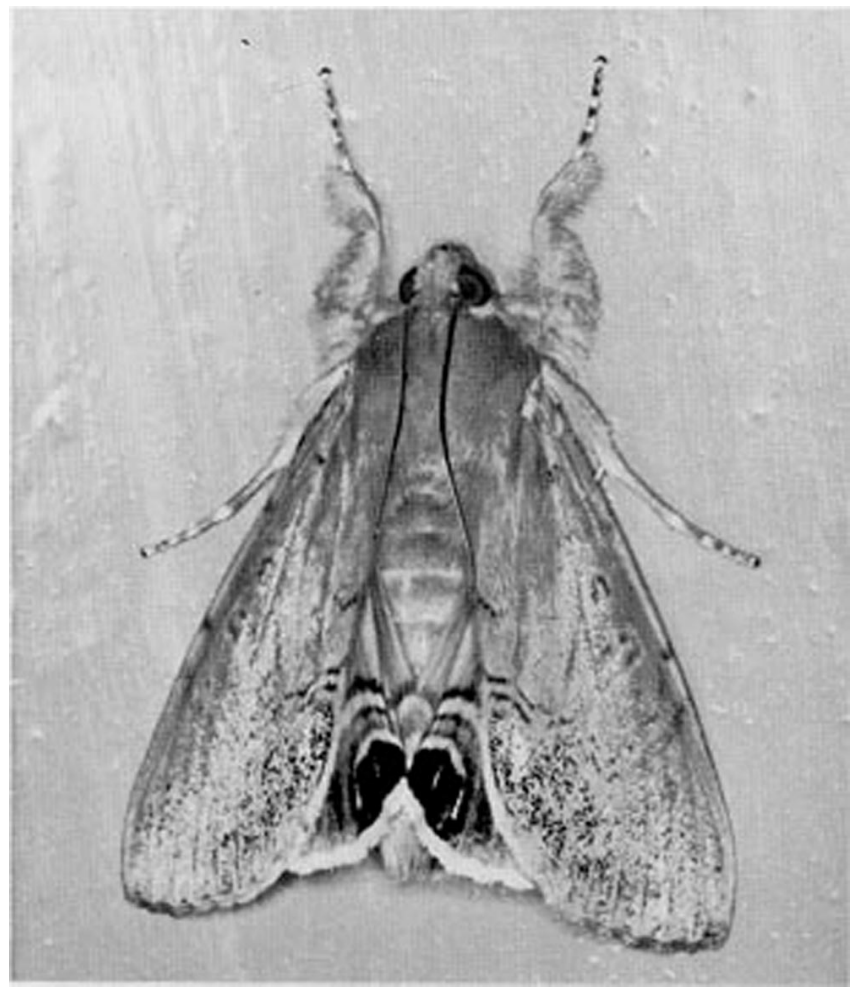

Figure 4. Adult cabbage palm caterpillar, Litoprosopus futilis (G. \& R.). Credits: Division of Plant Industry

they feed. The fully mature caterpillar may then drop to the ground on a silken thread and crawl to a protected pupation site or crawl down the trunk and beneath the base of a dead frond to construct a cocoon from dry palm fibers. In 1960, near Geneva, Florida, palms put forth a heavy bloom and a late larval population completely denuded the trees of all visible bloom.

\section{Economic Importance}

High populations of the cabbage palm caterpillar can drastically reduce the amount of palmetto honey produced in Florida. During such periods, the mature caterpillars have invaded homes and have been responsible for the loss of household fabrics. In making their cocoons, the caterpillars incorporate any available fabric, such as draperies, rugs, stuffed furniture, bedding and clothing. An outbreak in Miami, Florida in 1961 caused serious economic loss to fiberglass cloth used by the boat building industry.

\section{Management}

Protecting palm flowers from the cabbage palm caterpillar is difficult. Properly labeled insecticides or
Bacillus thuringeinsis $(\mathrm{Bt})$ formulations could be applied to the trees when caterpillars are present, but in order to be effective such an endeavor would require careful monitoring to properly time the application.

Because cabbage palm caterpillars will enter structures to pupate, it may be important to find their entry points and block them. However, not all materials will stop these caterpillars, as they can chew through fiberglass window screen and have been observed chewing on drywall. Cabbage palm caterpillar adults are strongly attracted to lights and during outbreak years, moths can enter structures and be a nuisance. Again, find and block entry points with caulk or screen.

Biological control may be important in the reduction cabbage palm caterpillar populations but this method of management has not been explored. Parasitoids or pathogens may be more useful than predators, primarily because the larvae produce an oral regurgitant when disturbed and the discharged material appears to be a deterrent against some predators.

\section{Selected References}

Crumb, S.E. 1956. The larvae of the Phalaenidae, USDA Tech. Bull. 1135: 327.

Kimball, C.P. 1965. Lepidoptera of Florida. Arthropods of Florida, Fla. Dept. of Agr. 1: 135.

Smedley, S.R., E. Ehrhardt \& T. Eisner. 1993. Defensive regurgitation by a noctuid moth larva (Litoprosopus futilis). Psyche 100: 209-221. 